\title{
EARLY SILURIAN CHITINOZOANS IN THE APUCARANA SUB-BASIN (PARANÁ BASIN), SOUTH BRAZIL, AND THEIR BIOSTRATIGRAPHIC PROVENANCE
}

\author{
YNGVE GRAHN \\ Faculdade de Geologia, UERJ, B1. A/4001, Rua São Francisco Xavier 524, 20550-013, Rio de Janeiro, RJ, Brazil. \\ yngvegrahn@hotmail.com
}

\begin{abstract}
Early Silurian chitinozoans recovered from cuttings samples of pre-Silurian units of the PETROBRAS 1-SE-1-SC well, near Seara in the State of Santa Catarina, southern Brazil, are compared with those from shales in the lower part of the Vargas Peña Formation at Minas Cué and the Asunción-1 well, eastern Paraguay. The obviously caved assemblages show a pronounced similarity with chitinozoan faunas belonging to the regional Spinachitina wolfarti - Plectochitina sp. A Subzone (Conochitina elongata Zone) of early Aeronian (early middle Llandovery) age. Because of down hole contamination, a stratigraphic provenance from the early Aeronian Vila Maria Formation is proposed.
\end{abstract}

Key words: Early Silurian, Paraná Basin, Chitinozoa.

\begin{abstract}
RESUMO - Quitinozoários eo-silurianos presentes em amostras de calha contaminada por desabamento (caving), procedentes de dois distintos intervalos estratigráficos, sendo Paleozóico (pré-Siluriano) e outro pré-cambriano tardio do poço da PETROBRAS 1-SE-1-SC (Seara, Estado de Santa Catarina, sul do Brasil), são comparados com outros de mesma idade, ocorrentes em folhelhos da parte inferior da Formação Vargas Peña em Minas Cué e no poço Asunción-1, no Paraguai oriental. Constata-se uma estreita similaridade entre ambas as quitinofaunas, sugerindo para o material brasileiro uma atribuição à Subzona regional Spinachitina wolfarti - Plectochitina sp. A (Zona de Conochitina elongata), do eo-Aeroniano (parte mais antiga do Llandovery médio). Sua procedência estratigráfica é atribuída à Formação Vila Maria, situada acima do intervalo de profundidades onde os quitinozoários foram encontrados.
\end{abstract}

Palavras-chave: Eo-siluriano, bacia do Paraná, Quitinozoários.

\section{INTRODUCTION}

The presence of Silurian rocks in the Paraná Basin was first recognized by Harrington (1950) for basal shales in eastern Paraguay. These shales were later formally named the Vargas Peña Shale by Wolfart (1961) and, based on the presence of Climacograptus, they were assigned an Early Silurian age. The Vargas Peña clay pit was chosen as a type locality (Harrington, 1972; Wood \& Miller, 1991). Shales in the same stratigraphic position in southern Brazil were defined as the Vila Maria Formation by Andrade and Camarço (1980). Faria (1982) described the Vila Maria lithologically and designated a type locality near Vila Maria, south of Arenópolis town in the State of Goiás, southern Brazil. Zalán et al. (1987) divided the formation into the Vila Maria Formation s.s. and the underlying Rio Ivaí Formation. They also defined three units of the Vila Maria Formation, a lower glaciogenic part, a middle unit with greenish-grey to brown calcareous shale that has yielded most of the reported fossils, and a upper part with calcareous sandstones and siltstones. The lower part of the than Rio Ivaí Formation contain Vendian fossils, and is therefore referred to the Itajai Group (Paim et al., 1997; Netto \& Martini da Rosa, 2003; Teixeira et al., 2004). A detailed lithological study of the Vila Maria Formation has been published by Pereira (1998).

In the Vila Maria Formation, a few metres below the contact with the overlying Furnas Formation, trace fossils occur that suggest an Ordovician or Silurian age (Burjack \& Popp, 1981). Bivalves, gastropods and inarticulate brachiopods from the Vila Maria Formation have been described by Popp et al. (1981), and the gastropod Plectonotus (Plectonotus) derbyi Clarke, 1899 was identified by Boucot et al. (1986). The trace fossils and the invertebrate body fossils are in tentative, but not conclusive, agreement with a Silurian age for the Vila Maria Formation. Faria (1982), Milani \& Daemon (1992), Milani et al. (1995) and Borghi et al. (1997) suggested a correlation with the Vargas Peña Formation of eastern Paraguay based on fossil content and lithology. The middle 
shaly unit of the Vila Maria Formation has been the object of different attempts to age date this unit using palynomorphs. Gray et al. (1985) were the first to date the Vila Maria Shale as conclusively Silurian (Rhuddanian; early Llandovery) based on tetrahedral tetrads of land plants together with acritarchs and prasinophytes. Grahn (1991, 1992) dated the Vila Maria Formation as early-middle Llandovery (Rhuddanian - Aeronian) based on available chitinozoan information. Laranjeira et al. (1997) investigated cryptospores (pseudodyads and tetrads) and rare trilete spores recovered from the Vila Maria shale and suggested the same age interpretation as Grahn (1991, 1992). Radiometric dating with the Rb-Sr method on fresh rock samples of the Vila Maria shales from Três Barras Farm, State of Goiás by Mizusaki et al. (2002) indicated an age of $435.9 \pm 7.8 \mathrm{MY}$, and the authors placed the Vila Maria Shale in the Rhuddanian - early Aeronian interval (see also Steemans \& Pereira, 2002). The present study is the first attempt to correlate the Silurian chitinozoans from the 1-SE1-SC well with those from the better known Vargas Peña Formation in eastern Paraguay (Milani \& Daemon, 1992; Milani et al., 1995; Grahn et al., 2000; Mendlowicz Mauller et al., 2004) and other contemporaneous strata in Brazil. Comprehensive reviews of the Vila Maria Formation can be found in Grahn (1992), Pereira (1998), and Grahn et al. (2000), and for the Vargas Peña Formation in Wood \& Miller (1991) and Grahn et al. (2000).

\section{MATERIAL AND METHODS}

Seventeen samples, some of which yielded a rich chitinozoan assemblages, were investigated from PETROBRAS 1-SE-1-SC well (down hole mostly contaminated cuttings from the Paleozoic early Silurian Vila Maria Formation [3230 - 3288 m] levels 3234, 3253, and 3279 m, pre-Silurian Rio Ivaí Formation [3288 - 3625 m] levels 3399,3453 and $3486 \mathrm{~m}$, the Late Precambrian (Vendian) Itajai Group [3625 - TD 4000 m] levels 3636, 3645, 3696, 3732, 3750,3786 , and $3936 \mathrm{~m}$ ), Minas Cué outcrop locality and the Asunción-1 well (cuttings from levels 2790, 2810, and 2820 $\mathrm{m})$. The geographical positions of these localities are shown in Figure 1. The organic residues were studied for chitinozoans using a binocular stereoscopic microscope, and representative chitinozoan specimens were picked for scanning electron microscope (SEM) studies in co-operation with the Applied Biostratigraphy and Paleoecology Management (BPA) at PETROBRAS Research and Development Center (CENPES) in Rio de Janeiro, Brazil. Sample processing and SEM preparations were done according to the techniques described by Laufeld (1974). Most of the chitinozoan specimens recovered are compressed, and a correction factor of 0.8 (Paris, 1981; Jaglin, 1986) was used to calculate the uncompressed dimensions (values given in brackets) of the specimens. All photographed chitinozoans are stored at the Department of Stratigraphy and Paleontology at Universidade do Estado do Rio de Janeiro (UERJ/DEPA).

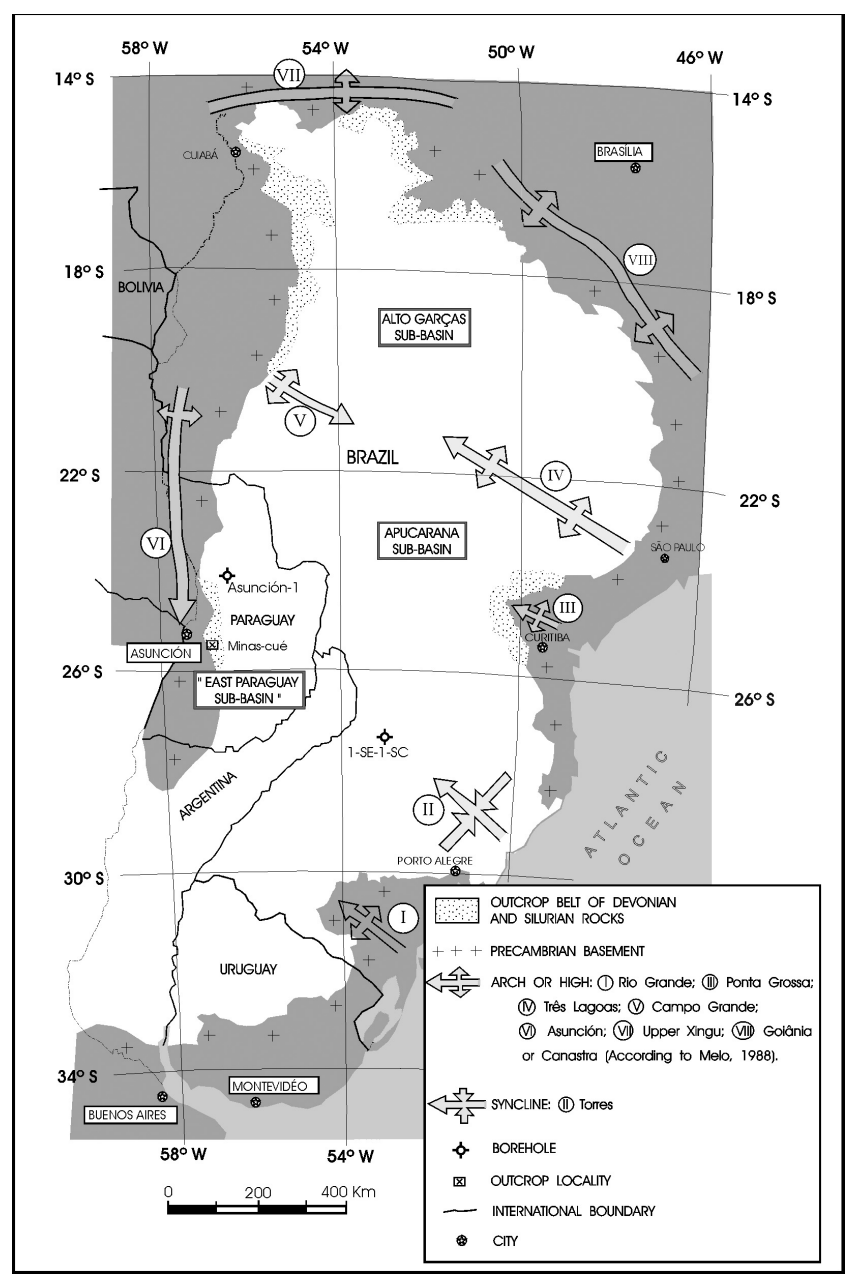

Figure 1. Map showing the geographical position of investigated localities in the Paraná Basin, Brazil and Paraguay (after Grahn et al., 2000). Dark grey color symbolizes older precambrian terrain.

\section{CHITINOZOAN BIOSTRATIGRAPHY}

Altogether ten chitinozoan species were encountered in the investigated samples (Figure 3 ). Their regional stratigraphical ranges in the studied areas are given in Figure 2. Besides Ancyrochitina primitiva?, Cyathochitina cf. campanulaeformis and Cyathochitina sp. B, which are longranging Silurian species with a wide geographical distribution, the other species present have only been reported from the Early Silurian of western Gondwana (South America)(own observations). The lack of age-definitive megafossils in the Vila Maria Formation and the lower Vargas Peña Formation stress the importance of microfossils as biostratigraphic tools. Milani \& Daemon (1992) and Milani et al. (1995) illustrated and determined chitinozoans from the Early Silurian of the Paraná Basin to generic level (one specimen was assigned to Ancyrochitina laevensis [= Ancyrochitina sp.], see Milani \& Daemon 1992, plate 1, fig. $\mathrm{B}$, which is an early Rhuddanian species). These illustrated specimens were later determined to species level (Grahn et al. 2000). The presence of Spinachitina is characteristic for the Aeronian of western Gondwana, where this genus appears 


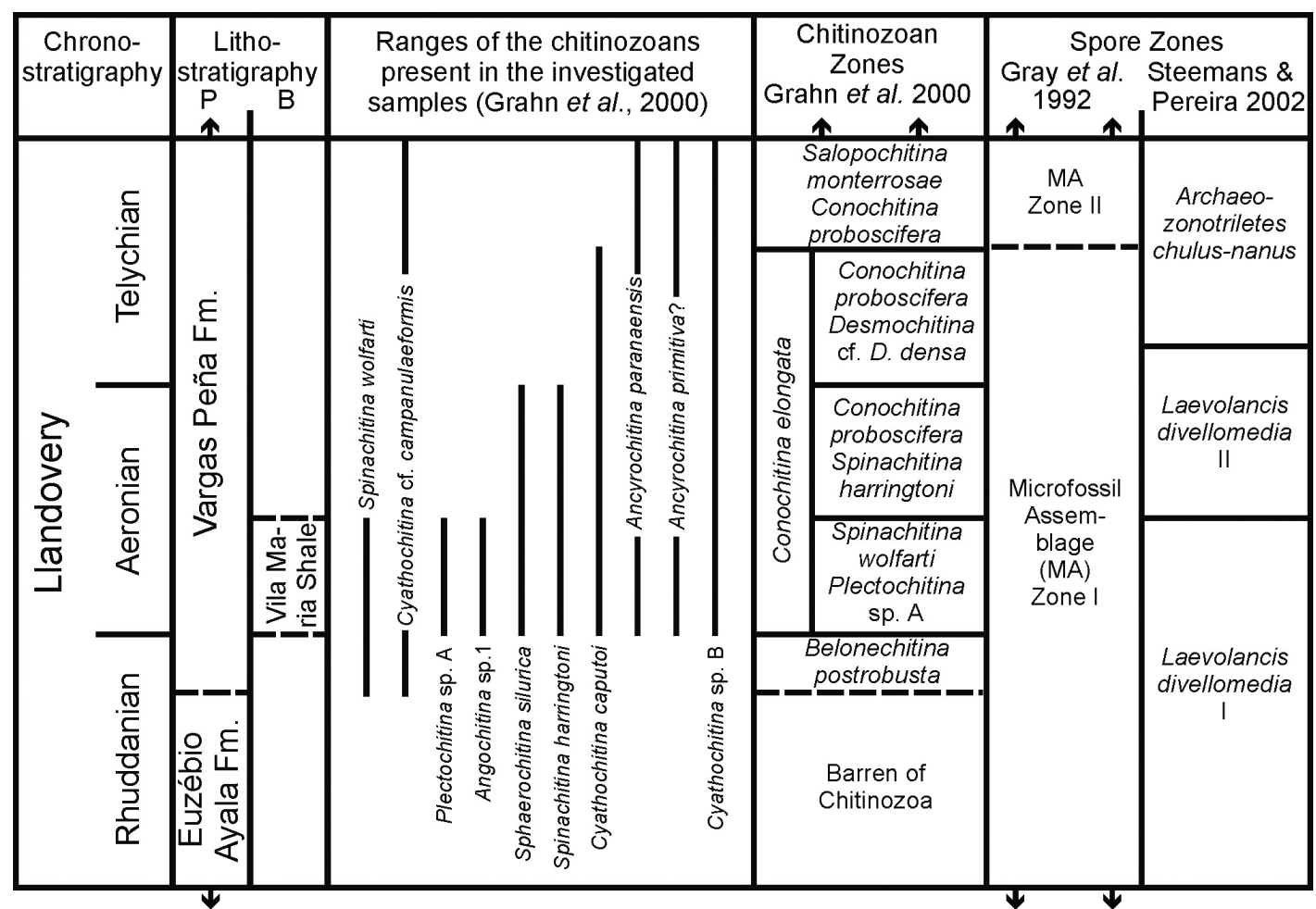

Figure 2. Integrated correlation of the chitinozoan species ranges in the investigated samples compared with Llandovery chitinozoan and spore successions of the Paraná Basin; $\mathrm{P}=$ Paraguay, $\mathrm{B}=$ Brazil.

in the latest Rhuddanian, reaches its maximum during the early Aeronian and disappears in the late Aeronian. It is a common genus in the lower part of the Vargas Peña Formation. The zonal index species Spinachitina wolfarti and/or Plectochitina sp. A sensu Grahn in Grahn et al. (2000) occur in all the three localities indicating the presence of the Spinachitina wolfarti - Plectochitina sp. A Subzone (Grahn et al., 2000). This subzone is tentatively assigned to the early Aeronian, and suggests that chitinozoans from the 1-SE-1$\mathrm{SC}$ well, and the lower part of Vargas Peña Formation, are of this age, which agrees with the miospore age interpretation (Mizusaki et al. 2002; Steemans \& Pereira, 2002). All chitinozoan species present are known from the literature, except for Angochitina sp.1, which is described in the Systematic Paleontology section. The chitinozoan occurrences at the three localities are summarized as follows. Minas Cué outcrop (25 31' 28" S, 56 50' 59" W). Vargas Peña Formation. Cyathochitina caputoi Costa, 1971, Cyathochitina cf. campanulaeformis (Eisenack, 1931), Plectochitina sp. A sensu Grahn in Grahn et al. (2000), Sphaerochitina silurica Grahn in Grahn et al. (2000), Spinachitina harringtoni Grahn in Grahn et al. (2000), and Spinachitina wolfarti Grahn in Grahn et al. (2000).

Asunción-1 well (24 4' 12.55' S, 56 27' 12.42' W). Vargas Peña Formation. 2730? - 2830 m. Samples: 2790 m. Spinachitina wolfarti. $2810 \mathrm{~m}$. Angochitina sp.1, Cyathochitina sp. B sensu Paris, 1981, and Spinachitina wolfarti. 2820 m. Ancyrochitina primitiva? Eisenack, 1964, Angochitina sp.1, and Spinachitina harringtoni.

1-SE-1-SC well (27' 8' 36.4' S, 52 $17^{\circ}$ ' 54.5'W). Vila Maria Formation. 3230 - 3288 m. Samples: 3234 m. Barren of chitinozoans. 3253 m. Barren of chitinozoans. 3279 m. Barren of chitinozoans. Rio Ivaí Formation. 3288 - 3625 m. Samples: 3399 m. Barren of chitinozoans. 3453 m. Angochitina sp.1. 3486 m. Ancyrochitina primitiva? Itajai Group. 3625 - TD 4000 m. Samples: 3636 m. Angochitina sp.1. and Cyathochitina sp. B. 3645 m. Ancyrochitina paranaensis Grahn in Grahn et al. (2000) and Cyathochitina sp. B. 3696 m. Angochitina sp.1. and Spinachitina wolfarti. $3732 \mathrm{~m}$. Angochitina sp. 1.3750 m. Barren of chitinozoans. $3786 \mathrm{~m}$. Angochitina sp. 1 and Cyathochitina sp. B. 3936 m. Plectochitina sp. A.

\section{SYSTEMATIC PALEONTOLOGY}

The systematic inventory of the chitinozoans in alphabetical order by genus and species is presented below and illustred in the Figure 3. Citations relating to the naming of these species are given in the references. The taxonomy used here follows that proposed by Paris et al. (1999). Only the previously undescribed species Angochitina sp. 1 will be described here.

Ancyrochitina paranaensis Grahn in Grahn et al. (2000). Ancyrochitina primitiva? Eisenack 1964.

Angochitina sp. 1.

Cyathochitina cf. campanulaeformis (Eisenack 1931).

Cyathochitina caputoi Costa 1971.

Cyathochitina sp. B sensu Paris 1981.

Plectochitina sp. A sensu Grahn in Grahn et al. (2000).

Sphaerochitina silurica Grahn in Grahn et al. (2000). Spinachitina harringtoni Grahn in Grahn et al. (2000). Spinachitina wolfarti Grahn in Grahn et al. (2000). 


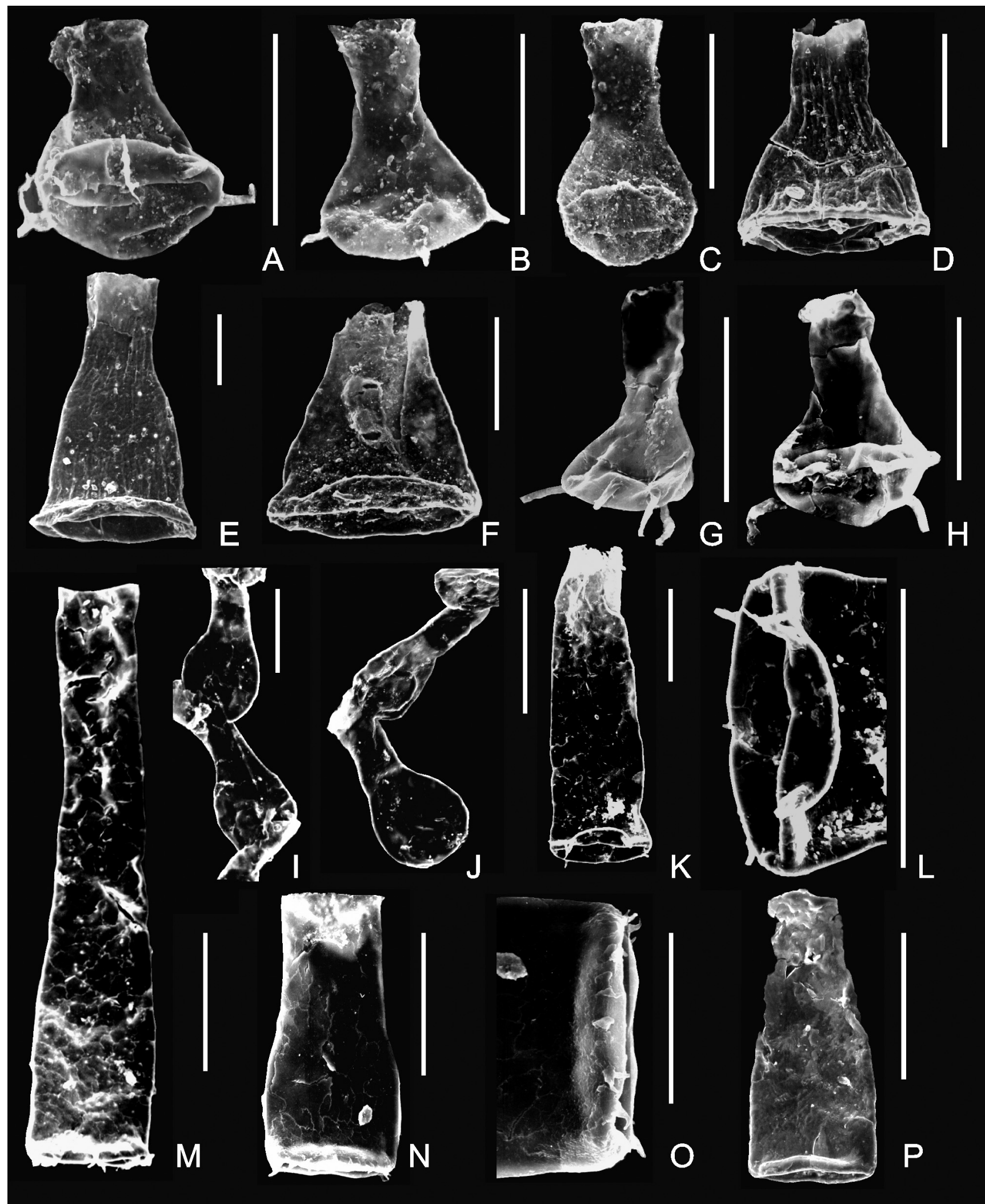

Figure 3. Chitinozoans from the Vargas Peña and Vila Maria formations. A, Ancyrochitina paranaensis, down hole contamination in Itajaí Group, well 1-SE-1-SC, 3645 m; B, Ancyrochitina primitiva?, Vargas Peña Formation, well Asunción-1, 2820 m; C, Angochitina sp. 1, Down hole contamination in Itajaí Group, well 1-SE-1-SC, 3732 m; D, Cyathochitina caputoi. Vargas Peña Formation. Minas Cué; E, Cyathochitina cf. campanulaeformis. Vargas Peña Formation. Minas Cué; F, Cyathochitina sp. B. Down hole contamination in Itajaí Group. Well 1-SE-1-SC, 3645 m; G-H, Plectochitina sp. A. Vargas Peña Formation; Minas Cué; I-J, Sphaerochitina silurica, Vargas Peña Formation, Minas Cué: I, chain with four specimens.; J, two specimens in a chain; K-M, Spinachitina harringtoni, Vargas Peña Formation, Minas Cué; L, detail of the specimen in figure K; N-P, Spinachitina wolfarti, Vargas Peña Formation, Minas Cué; O, detail of the specimen in figure $\mathrm{N}$. The scale bars for figures $\mathrm{A}-\mathrm{N}$ and $\mathrm{P}$ represent $100 \mu \mathrm{m}$, and $50 \mu \mathrm{m}$ for figure $\mathrm{O}$. 


\section{Group CHITINOZOA Eisenack, 1931 \\ Order PROSOMATIFERA Eisenack, 1972}

Family LAGENOCHITINIDAEEisenack, 1931 emend. Paris, 1981

Subfamily ANGOCHITININAE Paris, 1981

Genus ANGOCHITINA Eisenack, 1931

\section{Angochitina sp.1}

(Figure 3C)

Description. This Angochitina species has a spherical body and a cylindrical neck widening towards the straight aperture. The vesicle is covered by minute simple spines. In wellpreserved specimens, the flanks and neck display a gentle concave curve towards the aperture.

Dimensions. Eight specimens measured. Total length 125$154 \mu \mathrm{m}$; maximum width 68(54)-83(66) $\mu \mathrm{m}$; width of aperture $39(31)-50(40) \mu \mathrm{m}$; length of neck ca. $1 / 3$ of the total length; length of spines $\leq 4 \mu \mathrm{m}$.

Occurrence. Vila Maria and lower Vargas Peña formations, Paraná Basin, Brazil and Paraguay. Asunción-1 (levels 2810 and $2820 \mathrm{~m}$ ) and 1-SE-1-SC (contaminated samples from levels 3453, 3636, 3696, 3732, and $3786 \mathrm{~m}$ ). The Spinachitina wolfarti - Plectochitina sp. A Subzone (Conochitina elongata Zone). Tentatively dated as early Aeronian (early middle Llandovery).

\section{CONCLUDING REMARKS}

Biostratigraphic age control for the Vila Maria Formation is only possible using cryptospores. A suite of samples from Três Barras Farm, Goiás State, southern Brazil (Mizusaki et al., 2002), contained palynomorphs belonging to the Laevolancis divellomedia Interval Biozone I for the Vila Maria Shale. Steemans \& Pereira (2002) identified the same cryptospore zone and proposed an early Aeronian age for the lower Vargas Peña Formation. Gray et al. (1985) investigated spores in one sample from the same locality as Mizusaki et al. (2002). The phytoplankton assemblage present corresponds to the upper, but not the uppermost part, of Gray's (1985) Microfossil Assemblage Zone I, which ranges from the Llanvirn (beneath the Didymograptus murchisoni graptolite Zone) to the midTelychian (Gray, 1989; Gray et al., 1992). No detailed biostratigraphic study of the acritarchs (Gray et al., 1985; Wood \& Miller, 1991) have been made, but the acritarchs from the Vila Maria Formation display Aeronian elements (cf. Le Hérissé et al., 1995, 2001; Molyneux et al., 1996).

Chitinozoans are rare in the Vila Maria Formation, and have only been found for certain as down hole contamination in older beds from 1-SE-1-SC well. Finds at Aldeia Creek, reported by Grahn et al. (2000), are as pointed out by the authors, questionable, since the actual locality has not been relocated. Plectochitina sp. A, one of the index species for the Spinachitina wolfarti - Plectochitina sp. A Subzone (Conochitina elongata Zone), occurs in the 1-SE-1-SC well. Further, Angochitina sp.1 is present in the 1-SE-1-SC, and it occurs together with Spinachitina wolfarti in Paraguay
(Grahn in Grahn et al., 2000). Ancyrochitina paranaensis, another species from the 1-SE-1-SC, was first described from the Early Silurian of Paraguay by Grahn et al. (2000), and from the Vargas Peña clay pit as Ancyrochitina sp. by Miller (1996) and Ancyrochitina sp. 5 (Wood \& Miller, 1997, pers. Commun.). It was first reported to range from upper Aeronian to Telychian (Grahn et al., 2000), but this study shows that the species appeared already in the lower Aeronian. Cyathochitina sp. B is a common Llandovery species in the intracratonic basins of Brazil and Paraguay. Altogether this indicates an early Aeronian age for the caved Vila Maria Shale chitinozoans in 1-SE-1-SC, and the lower part of the Vargas Peña Formation.

\section{ACKNOWLEDGMENTS}

Thanks are due to the Faculty of Geology at UERJ, and to Egberto Pereira, for access to the facilities of this institution. The SEM photographs were taken by José Henrique G. de Melo (BPA/CENPES/PETROBRAS), who also made the translations into Portuguese. F. John Gregory, Stewart G. Molyneux and an anonymous referee are acknowledged for reviewing an earlier version of the manuscript, and Peter Isaacson for reading it and checking the English. I am very grateful to Merrell A. Miller for his careful English revision of the final version of the ms, which led to a much improved work. My sincere thanks are extended to all these collegues.

\section{REFERENCES}

Andrade, S.M. \& Camarço, P.E.N. 1980. Estratigrafia dos sedimentos devonianos do flanco nordeste da bacia do Paraná. In: CONGRESSO BRASILEIRO DE GEOLOGIA, 31, 1980. Anais, Camboriú, SBG, 5: 2828-2836.

Borghi, L; Orué, D; Figueredo, L.B.; Alvarenga, D. \& Clérice, A.M.C. 1997. Correlation between the Itacurubí Group (Paraguay) and the Vila Maria Formation (Brazil), Silurian of the Paraná Basin. In: SIMPÓSIO SOBRE A CRONOESTRATIGRAFIA DA BACIA DO PARANÁ, 3, 1997. Boletim de Resumos, Barra do Garças, UERJ, p. 7.

Boucot, A.J.; Rohr, D.M.; Gray, J.; Faria, A. \& Colbath, G.K. 1986. Plectonotus and Plectonotoides, new subgenus of Plectonotus (Bellerophontacea: Gastropoda) and th e i r biostratigraphic significance. Neues Jahrbuch für Geologie und Paläontologie, Abhandlungen, 173:167-180.

Burjack, M.I. \& Popp, M.T.B. 1981. A ocorrência do icnogênero Arthrophycus no Paleozóico da Bacia do Paraná. Pesquisas, 14:163-168.

Clarke, J.M. 1899. A fauna siluriana superior do Rio Trombetas. Archivos do Museu Nacional, 10:1-48.

Costa, N.M. 1971. Quitinozoários brasileiros e sua importância estratigráfica. Anais da Academia Brasileira de Ciências, 43:209-272.

Eisenack, A. 1931. Neue Mikrofossilien des baltischen Silurs. 1. Paläontologische Zeitschrift, 13:74-118.

Eisenack, A. 1964. Mikrofossilien aus dem Silur Gotlands. Chitinozoen. Neues Jahrbuch für Geologie und Paläontologie, Abhandlungen, 120:308-342. 
Eisenack, A. 1972. Beitrage zur Chitinozoen-Forschung. Palaeontographica A, 140:117-130.

Faria, A. 1982. Formação Vila Maria - Nova unidade litoestratigráfia siluriana da Bacia do Paraná. Ciências da Terra, 3:12-15.

Grahn, Y. 1991. The Ordovician-Devonian biostratigraphy of Brazil. Anais da Academia Brasileira de Ciências, 63(1):p.94.

Grahn, Y. 1992. Revision of Silurian and Devonian strata of Brazil. Palynology, 16:35-61.

Grahn, Y.; Pereira, E. \& Bergamaschi, S. 2000: Silurian and Lower Devonian chitinozoan biostratigraphy of the Paraná Basin in Brazil and Paraguay. Palynology, 24:147-176.

Gray, J. 1985. The microfossil record of early land plants; advances in understanding of early terrestrialization, 1970-1984. In: W.G. Chaloner \& J.D. Lawson (eds.) Evolution and environment in the Late Silurian and Early Devonian. Philosophical Transactions of the Royal Society of London, B 309: 167-195.

Gray, J. 1989. Adaptive radiation of early land plants. In: INTERNATIONAL GEOLOGICAL CONGRESS, 28, 1989. Abstracts, Washington, IUGS, 1:582-583.

Gray, J.; Colbath, G.K.; Faria, A.; Boucot, A.J. \& Rohr, D.M. 1985. Silurian age fossils from the Paleozoic Paraná Basin, Brazil. Geology, 13:521-525.

Gray, J.; Boucot, A.J.; Grahn, Y. \& Himes, G. 1992. A new record of Early Silurian land plant spores from the Paraná Basin, Paraguay (Malvinokaffric Realm). Geological Magazine, 129:741-752.

Harrington, H.J. 1950. Geología del Paraguay Oriental. Buenos Aires, Facultad de Ciências Exactas, Físicas y Naturales, 82 p. (Contribuciones Científicas, Ser. E, Geologia 1).

Harrington, H.J. 1972. Silurian of Paraguay. In: W.B.N. Berry \& A.J. Boucot (eds). Correlation of the South American Silurian rocks. Geological Society of America, Special Paper, 133:41-50.

Jaglin, J.C. 1986. Nouvelles espèces de Chitinozoaires du Pridolí de Libye. Revue de Micropaléontologie, 29:44-54.

Laranjeira, N.P.F.; Melo, J.H.G. \& Pereira, E. 1997. New palynological dating of the Vila Maria Formation (Silurian, Paraná Basin) in southwestern Goiás State, west-central Brazil. In: SIMPÓSIO SOBRE A CRONOESTRATIGRAFIA DA BACIA DO PARANÁ, 3, 1997. Boletim de Resumos, Barra do Garças, UERJ, p. 4-5.

Laufeld, S. 1974. Silurian Chitinozoa from Gotland. Fossils and Strata, 5:1-120.

Le Hérissé, A.; Al-Tayyar, H. \& van der Eem, H. 1995. Stratigraphic and paleogeographical significance of Silurian acritarchs from Saudi Arabia. Review of Palaeobotany and Palynology, 89:49-74.

Le Hérissé, A.; Melo, J.H.G.; Quadros, L.P.; Grahn, Y. \& Steemans, P. 2001. Palynological characterization and dating of the Tianguá Formation, Serra Grande Group, northern Brazil. In: J.H.G. Melo \& G.J.S. Terra (eds.) Correlação de Seqüências Paleozóicas Sul-Americanas. Ciência Técnica Petróleo. Seção: Exploração de Petróleo, 20:25-41.

Melo, J.H.G. 1988. The Malvinokaffric realm in the Devonian of Brazil. In: N.J. McMillan; A.F. Embry \& D.J. Glass (eds.) Devonian of the World. Canadian Society of Petroleum Geologists Memoir, Volume 1, 14:669-703.

Mendlowicz Mauller, P.; Pereira, E.; Grahn, Y. \& Steemans, P. 2004. Análise bioestratigráfica do intervalo Llandoveriano da Bacia do Paraná no Paraguai oriental. Revista Brasileira de Paleontologia, 7(2):199-212.

Milani, E.J. \& Daemon, R.F. 1992. Revisão bio- e litoestratigráfica da seção siluro-devoniana dos poços Asunción-1 e Asunción-2 (Pecten, Paraguai). Internal report, PETROBRAS/ NEXPAR,Curitiba, p. 1-19.

Milani, E.J; Assine, M.L; Soares, P.C. \& Daemon, R.F. 1995. A seqüencia ordovicio- siluriana da Bacia do Paraná. Boletim de Geociências da Petrobrás, 9:301-320.

Miller, M.A. 1996. Chitinozoa. In. J. Jansonius \& D.C. McGregor (eds) Palynology: principles and applications. American Association of Stratigraphic Palynologists Foundation, 1:307-336.

Mizusaki, A.M.; Melo, J.H.G.; Vignol-Lelarge, M.L. \& Steemans, P. 2002. Vila Maria Formation (Silurian, Paraná Basin, Brazil): integrated radiometric and palynological age determinations. Geological Magazine, 139:453-463.

Molyneux, S.G.; Le Hérissé, A. \& Wicander, R. 1996. Paleozoic phytoplankton In: J. Jansonius \& D.C. McGregor (eds.) Palynology: principles and applications. American Association of Stratigraphic Palynologists Foundation, 2: 493-529.

Netto, R.G. \& Martini da Rosa, C.L. 2003. When life left the sea: evidence of ecospace colonization of Vendian marginal marine environments. In: LATINAMERICAN CONGRESS OF SEDIMENTOLOGY, 3, 2003. Abstracts, Belém, IAS, p. 178.

Paim, P.S.G.; Leipnitz, I.; da Rosa, A.A.S. \& Zucatti da Rosa, A.L. 1997. Preliminary Report on the occurrence of Chancellonia sp. in the Itajaí Basin, Southern Brazil. Revista Brasileira Geosciencias, 27:303-308.

Paris, F. 1981. Les Chitinozoaires dans le Paleozoïque du sudouest de l'Europe (Cadre géologique - Etude systématique Bioestratigraphie). Mémoires de la Société géologique et mineralogique de Bretagne, 26:1-412.

Paris, F.; Grahn, Y.; Nestor, V. \& Lakova, I. 1999. Proposal for a revised chitinozoan classification. Journal of Paleontology, 73:549-570.

Pereira, E. 1998. Estratigrafia da Formação Vila Maria (Landoveriano), na Sub-Bacia de Alto Garças (Bacia do Paraná), Brasil. Anais da Academia Brasileira de Ciências, 70:501-525.

Popp, M.T.B.; Burjack, M.I. \& Esteves, I.R.F. 1981. Estudo preliminar sobre o conteúdo paleontológico da Formação Vila Maria (pré-Devoniano) da Bacia do Paraná. Pesquisas, 14:169-180.

Steemans, P. \& Pereira, E. 2002. Llandovery miospore biostratigraphy and stratigraphic evolution of the Paraná Basin, Paraguay - Palaeogeographic implications. Bulletin Societé geologique de France, 173:407-414.

Teixeira, A.L.; Gaucher, C.; Paim, P.S.G.; Fonseca, M.M.; Parente, C.V.P.; Silva Filho, W.F. \& Almeida, A.R. 2004. Capítulo XXIX. Bacias do Estágio da transição da Plataforma Sul-Americana. In: V. Mantesso-Neto; A. Bartorelli; C.D.R. Carneiro \& B.B. de Brito-Neves (eds) Geologia do Continente Sul-Americano: evolução da obra de Fernando Flávio Marques de Almeida, BECA, p. 487-537.

Wolfart, R. 1961. Stratigraphie und Fauna des älteren Paleozoikums (Silur, Devon) in Paraguay. Geologische Jahrbuch, 78:29-102.

Wood, G.D. \& Miller, M.A. 1991. Distinctive Silurian chitinozoans from the Itacurubí Group (Vargas Peña Shale), Chaco

Zalán, P.V.; Wolff, S.; Conceição, J.C.J.; Vieira, I.S.; Astolfi, M.A.M; Appi, V.T. \& Zanotto, O.A. 1987. Divisão tripartite do Siluriano da Bacia do Paraná. Revista Brasileira de Geociências, 17:242-252.

Received April, 2005; accepted August, 2005. 